\title{
From the Editor
}

$\mathrm{T}$ HIS YEAR at the Society for Business Ethics Annual Meeting in Philadephia, the winners of the 2014 Business Ethics Quarterly Best Article Award and Best Reviewer Award were announced (see p. vi). The awards were given for articles published in 2013 or reviews completed during 2013. The BEQ Associate Editors, Managing Editor, and Editor in Chief constitute the nominating committee for the Best Article award. The Best Article Award Committee was composed of Associate Editors Heather Elms (American University), Bruce Barry (Vanderbilt University), and Andreas Scherer (University of Zürich). Thanks to all the authors and reviewers whose contributions allow $B E Q$ to flourish in its distinctive role as the leading theoretical, multidisciplinary journal of business ethics and corporate social responsibility.

The 2013 journal impact factors have been released by Journal Citation Reports (Thomson Reuters). Many BEQ contributors will be interested to learn that as the reputation for high quality scholarship at Business Ethics Quarterly continues to grow, our impact scores continue to rise as well. $B E Q$ received a 2.702 on the 2 -year measure, and 3.486 on the 5-year impact measure. Its 2-year impact factor with self-citations removed is 2.149 , indicating that $B E Q$ articles are being widely engaged in other academic journals. According to Journal Citation Reports, $B E Q$ is currently ranked \#1 of 50 journals in the Ethics category and 16th out of 110 journals in the Business category.

Partly as a result of our past success, the Society for Business Ethics Board of Directors has decided to engage a new publisher for $B E Q$ in 2015 to facilitate the continued growth and development of the journal internationally. For the last twentyfour years the Philosophy Documentation Center (PDC) has published $B E Q$ ably and well. George Leaman and his team have provided invaluable service that permitted $B E Q$ to mature and grow as a journal and reach a wide audience. $B E Q$ authors are familiar with the outstanding production editing work of Gregory Swope, who has helped ensure that $B E Q$ articles meet the highest standards of professional journal publication. We are grateful to everyone at PDC for their dedicated service over the last twenty-four years.

Denis G. Arnold

Editor in Chief 


\section{Best Reviewer Award}

Jason Stansbury, Calvin College

\section{Best Article Award}

Winner: Thomas M. Jones and Will Felps, "Stakeholder Happiness Enhancement: A Neo-Utilitarian Objective for the Modern Corporation," Business Ethics Quarterly 23:3 (July 2013): 349-79.

Finalist: Philipp Schreck, Dominik van Aaken, and Thomas Donaldson, "Positive Economics and the Normativistic Fallacy: Bridging the Two Sides of CSR," Business Ethics Quarterly 23:2 (April 2013): 297-329.

Finalist: Pete Tashman and Jonathan Raelin, "Who and What Really Matters to the Firm: Moving Stakeholder Salience beyond Managerial Perceptions," Business Ethics Quarterly 23:4 (October 2013): 591-616. 